\title{
Legal status of animals and proposals for amendments in congress in the Brazilian National Congress
}

Arthur Henrique de Pontes Regis ${ }^{1}$, Gabriele Cornelli ${ }^{2}$

\begin{abstract}
Human history is marked by the interaction with animals, which are directly related to various themes of social history, economic, material, cultural, religious and symbolic. However, the Brazilian legal system regards animals as objects. In this context, there was an exploratory research in the database of the National Congress, in order to try to locate legislative proposals that deal with the legal treatment offered to animals, identifying nine proposals that relate directly to the issue of the legal status of animals. The Brazilian legal system is founded on the anthropocentric view, but the existence of legislative proposals demonstrates the relevance of the debate to the legal realm and shows a chronological evolution in the view that animals would be entitled to rights, justified by their recognition as sentient beings.

Keywords: Bioethics. Draft bill. Animal welfare. Environmental legislation.
\end{abstract}

\section{Resumo}

\section{Situação jurídica dos animais e propostas de alterações no Congresso Nacional}

A história humana é marcada pela interação com animais, os quais estão diretamente relacionados a várias temáticas da história social, econômica, material, cultural, religiosa e simbólica. Entretanto, o ordenamento jurídico brasileiro interpreta animais como objetos. Nesse contexto, realizou-se pesquisa exploratória no banco de dados do Congresso Nacional com objetivo de tentar localizar propostas legislativas que versem sobre o tratamento jurídico ofertado aos animais, identificando-se nove projetos de lei que se relacionam diretamente com a questão. $O$ ordenamento jurídico brasileiro está pautado na visão antropocêntrica, mas a existência de propostas legislativas demonstra a atração do debate para a seara jurídica e evidencia evolução cronológica da visão de que animais seriam detentores de direitos, justificados pelo reconhecimento de serem sencientes.

Palavras-chave: Bioética. Projeto de lei. Bem-estar animal. Legislação ambiental.

\section{Resumen}

Situación jurídica de los animales y propuestas de modificación en el Congreso de la Nación Brasileña

La historia humana está marcada por la interacción con los animales, los cuales están directamente relacionados con diversos temas de la historia social, económica, material, cultural, religiosa y simbólica. Sin embargo, el sistema jurídico brasilero entiende a los animales como objetos. En este contexto, se realizó una investigación exploratoria en la base de datos del Congreso Nacional, con el de localizar las propuestas legislativas que tienen que ver con el tratamiento legal ofrecido a los animales, identificándose nueve proyectos de ley que se relacionan directamente con la cuestión. El sistema jurídico brasilero se basa en una visión antropocéntrica, pero la existencia de propuestas legislativas demuestra la importancia del debate en el campo legal y pone en evidencia una evolución cronológica de la posición que admite que los animales serían detentores de derechos, justificándose en el reconocimiento de ser seres sensibles.

Palabras clave: Bioética. Proyecto de ley. Bienestar del animal. Legislación ambiental.

1. Doutorando ahpregis@gmail.com - Universidade de Brasília (UnB) 2. Doutor gabriele.cornelli@gmail.com - UnB, Brasília/DF, Brasil.

Correspondência

Arthur H. P. Regis - Rua Buriti, Residencial Águas de Tambaú, apt. 1.201, Águas Claras CEP 71910-180. Brasília/DF, Brasil.

Declaram não haver conflito de interesse. 


\section{On the relationship with animals}

Human history and development are marked by the interaction with animals (here defined as all non-human animals). Examples of their importance are in several activities and processes related to human beings, such as large scale production processes, be it in the exploitation of ocean resources, or in agricultural production, whether in intensive or extensive ${ }^{1}$.

One can think of them as a food source for the animals themselves, such as animal feed, especially in the form of flour; as a source of energy for traction equipments, as in agricultural equipments for planting and harvest; as means of transportation of humans and cargoes; as sources of a wide variety of raw materials for clothing, tools, ornaments, household utensils, etc.; as fuel - for example, the use of whale oil for lighting ${ }^{1}$.

There is also the possibility of using them for the natural control of pests and predators; in religious events, when animals are or were considered sacred, as well as the object of sacrifice; in sports and for the amusement of human beings, as in horse races, rodeos, circuses, zoos etc.; in the development of specific activities, such as guide dogs and police sniffer dogs ${ }^{1}$.

In the sciences, animal models are used in several branches of biological research and in various fields of biomedical research, provided that they meet certain conditions. They should allow for the study of biological phenomena or behavior of the animal, enable the investigation of a spontaneous or induced pathological process, and present the phenomenon in one or more aspects similar to that occurring in humans ${ }^{2}$. Scientific research and product testing, especially in the twentieth century, were fundamental to develop new drugs, to identify biological markers and to evaluate new techniques with perspectives of applicability in the human species ${ }^{3,4}$.

Stories, myths and other forms of representation involving animals are part of narratives recorded since prehistory. Examples of this are the cave drawings in the cave of Lascaux and other archaeological sites, including the Serra da Capivara National Park (Piauí, Brazil), where there are a large number of archaeological sites with several cave records. ${ }^{5,6}$.

Religions, mythology, and the universe of children, as well as historical and everyday events, are also filled with animals, such as the serpent that tempted Eve in paradise (directly related to the original sin), the animals in Noah's ark, the great fish of Jonah, the ox and the donkey in the Christmas Crib. ${ }^{\text {. }}$

In mythology and history, we have the minotaur of the island of Crete (creature with human body and the head of a bull), the owl of the goddess Athena (symbol of wisdom), the Roman wolf (responsible for feeding the twins Romulus and Remus), The elephants of Hannibal used in the war, the English King Richard, the Lionheart, the dogs of the French king Charles IX, the bees of Napoleon Bonaparte, and the beast of Gévaudan in eighteenth-century France ${ }^{7}$.

In the universe of children and in the realm of the fantastic, we find the animals of the fables of La Fontaine, Teddy bear (the first stuffed bear), Mickey Mouse, Donald Duck and his friends created by Walt Disney, the boars of Obélix and the Loch Ness Monster, among many others. Finally, in the field of genetics we have Dolly, the sheep, the first mammal cloned from an adult cell, which represented great scientific advance ${ }^{7}$.

Leaving the religious, and mythological fields and the one related to the universe of children, there are also the animals present in the literary works "Animal Farm" ${ }^{8}$, "The Metamorphosis" ${ }^{9}$ and "Alice in Wonderland" ${ }^{10}$, among others. Animals also permeate Brazilian folklore and tales: the lizard prince ("príncipe lagartão"), the frog princess ("princesa jia"), the husband of the "Water-Mother" ("Mãe d'Água", a folkloric being with the constitution of the mermaid), the bull and the man, the tortoise and the lizard ("o cágado e o teiú"), the frog in fear of water ("o sapo com medo d'água"), the fox and the opossum ("a raposa e o timbu"), the jaguar and the goat, the spider and the quibungo (a fantastic being of the Brazilian folklore, with the body of an animal, a large head and a hole in the back), the boy and the donkey ${ }^{11}$. it is, thus, evident that animals are directly related to several aspects of the social, economic, material, cultural, religious and symbolic histories of human beings.

\section{On the law as a historical social phenomenon}

The most embryonic forms of human conviviality were already ruled by a normative network which regulated the relationship between people, that is, there was already an outline of a law, since individuals played different social roles that were, in turn, governed by relations of power. 
From the encounter of human beings, the first rules, habits and customs arise by reiterating certain practices, characterizing themselves as the first structuring conducts of the normative framework of society ${ }^{12-15}$. Thus, even preliterate peoples had behaviors that governed the interactions between individuals (and still do, since there are still several isolated preliterate population groups).

These behaviors, in general, may be understood and interpreted as representing the role of the Law in those societies, although not termed this way by the very population that institutes this norm. This is because they deal with the regulation of social and everyday situations, such as marriage, property, hierarchy, among other interactions existing in each specific society ${ }^{16,17}$. Law, as a human construct, changes throughout history, being a historicalcultural phenomenon, reflecting the values of society in a certain time ${ }^{12,13,18,19}$. It may be used as a tool for diverging purposes, being characterized both as an important tool in the search for social peace and as a mechanism to perpetuate injustices ${ }^{20}$.

Legal norms reflect social (and also scientific) concepts of a given time, changing as society modifies its interpretation of social facts and evolves its scientific knowledge. For example, around 1950, when there were no technologies for assisted human reproduction, this alternative was not characterized as an object of attention to the Law, since the social fact was, until then, non-existent.

With the biotechnological advancement and the birth of the first test-tube baby - Louise Brown on July 25, 1978, in England - the social fact becomes object of attention and covered by the Law, especially with the edition of legal norms by the countries. In Brazil, the matter is currently regulated by Resolution 2.121 / 2015 of the Federal Council of Medicine ${ }^{21}$, there being no federal legislation on the subject, only legislative proposals still pending in the Brazilian National Congress.

Particularly regarding animals, the first protection law was created in 1822 in Great Britain and, in fact, protected the right to property, since it prohibited the animal belonging to a third party from being subjected to ill-treatment. In a specific way, over time, the laws of several countries have contemplated the protection of animals and/or the environment ${ }^{22}$. In the last decades, there has been a constant evolution of this perspective, especially from the construction of the thesis of the equal consideration of interests towards animals, based on the fact that animals are known to have the capacity to feel pain, and there is no moral basis for this suffering to be disconsidered. ${ }^{23}$ That is, animals are sentient beings which experience sensory or emotional suffering characterized as unpleasant, striving for it to end ${ }^{24}$.

In Brazil, the first norm to regulate animal protection was Decree $16,590 / 1924^{25}$. Presently in effect there are the Law 9,605/1998 (Law of Environmental Crimes or Nature's Law) ${ }^{26}$ and the Law-Decree 3,688/1941 (Law of Criminal Offenses) ${ }^{27}$. In the field of the use of animals in research, only in 2008 (Law 11,794, Arouca Law) ${ }^{28}$ there was specific regulation of the matter (after decades of a legal gap and years of legislative process). Ethical analysis of projects involving animals was instated, and the new legal framework was set up as an important milestone, which is constantly evolving through the publication of regulations by the National Council for the Control of Animal Experimentation ("Conselho Nacional de Controle de Experimentação Animal", Concea) ${ }^{29}$.

However, the current Brazilian legal system interprets wild animals as a common good for the use of the people (item VII, $\S 1$ o, of article 225 of the Brazilian Federal Constitution) ${ }^{30}$ and domestic animals as moving goods (article 82 of the Civil Code) ${ }^{31}$. That is, the norms in effect express the understanding that animals are objects.

\section{On draft laws in the Brazilian National Congress and their discussion}

Since animals are interpreted as objects in the law, an exploratory research was carried out in the National Congress database (which has as its primary competence the elaboration of laws). The objective was to find legislative proposals submitted up to 2015 and still in process dealing with the legal treatment offered to animals. The indices used were "animal" and "animals", identifying 242 Draft Laws, 26 in the Federal Senate and 216 in the Chamber of Representatives, nine of which are directly related to the issue of the legal status of animals, as presented in Frame 1.

The draft laws in progress demonstrate the interest of Brazilian congressmen in this matter, in the 21st century. The legislative proposals in the Federal Senate, for example, are all from 2015. The assignment of ill-treatment guides projects based on the anthropocentric perspective, acting simultaneously as a mechanism to reduce animal suffering and as a perpetuator and legalizer of existing practices (control activities, experimentation 
Frame 1. Draft Laws in process in the Brazilian legislative (2007-2015)

1) Senate Draft Law 351/2015 (Federal Senate) adds determination in the Civil Code so that animals are not considered things, mirroring in the legislation of countries like Switzerland, Germany, Austria and France, admitting that animals, although they are not recognized As natural persons, are not objects or things. However, there is no provision in the draft defining what the new status of animals would be. ${ }^{32}$.

2) Senate Draft Law 631/2015 (Federal Senate) proposes the Animal Statute, of which the objectives include combating ill-treatment and all forms of violence, cruelty and neglect towards animal species, recognizing them as sentient beings. Article 4 states that all animals in the national territory shall be protected by the State and have the right to exist in a context of biological and environmental balance, according to the diversity of species, races and individuals. However, the provisions of the legislative proposal only cover animals of the species classified in the phylum Chordata, subphylum Vertebrata, excluding all non-vertebrate animals from its scope of discrimination. Therefore, its purpose of ensuring and protecting the life and welfare of animals throughout the national territory, set forth in of its Article 1 , would be restricted to a certain group of animals ${ }^{33}$.

3) Senate Draft Law 650/2015 (Federal Senate) promotes the protection and defense of animal welfare and creates the National System for the Protection and Defense of Animal Welfare ("Sistema Nacional de Proteção e Defesa do Bem-Estar dos Animais", Sinapra) and the National Council for the Protection and Defense of Animal Welfare ("Conselho Nacional de Proteção e Defesa do Bem-Estar dos Animais", Conapra). It presents a wording similar to that of Senate Draft Law 631/2015, regarding its objectives, provision on animal rights and animal species covered by the legislation (only phylum Chordata, subphylum Vertebrata) ${ }^{34}$.

4) Senate Draft Law 677/2015 (Federal Senate) establishes the Animal Statute, which is designed to ensure the protection and welfare of animal life and applies only to vertebrates. However, it states that the standard can be applied to other animals, without specifying the situations of expansion of its scope. In its justification there is the recognition that animals are beings endowed with sensitivity and that their life and dignity are values that our society recognizes in its entirety ${ }^{35}$.

5) Draft Law 215/2007 (Chamber of Representatives) establishes the Federal Code of Animal Welfare ("Código Federal de Bem-Estar Animal"), establishing guidelines and standards to guarantee compliance with the principles of animal welfare in animal control, animal experimentation and animal production. Its primary objectives are to reduce and eliminate animal suffering, to defend animal rights and to promote animal welfare. In the meantime, there is no definition of what animal rights would be or whether animals would be entitled to rights, stating in its justification that Animal Welfare norms can not contain restrictions that make production or economics unfeasible, nor to dissociate from a scientific basis or to be based on anthropomorphic standards, making its anthropocentric bias explicit ${ }^{36}$.

6) Draft Law 2,156/2011 (Chamber of Representatives) provides for the National Code for the Protection of Animals (Código Nacional de Proteção aos Animais), listing a series of prohibited practices that violate the integrity of animals (such as physical aggression, exorbitant work, failure to provide quick and painless death for animals slaughtered for consumption, etc.). However, it is not clear whether the animals would be subjects of the law, justifying the proposition because animals are capable of experiencing many of the feelings that we ourselves experience (...), imposing on us the moral and ethical duty to avoid the suffering of these other beings ${ }^{37}$.

7) Draft Law 3,676 / 2012 (House of Representatives) elaborates the Statute of the Animals and declares that animals are sentient beings, subjects of natural rights and are born equal before life. It defines the fundamental rights of animals: respect for existence, dignified treatment, shelter, veterinary care and work in non-degrading conditions. It presents the definition of animal as every irrational living being, endowed with sensibility and movement ${ }^{38}$.

8) Draft Law 6,799/2013 (Chamber of Representatives) proposes that domestic and wild animals have a sui generis legal nature, being subject to depersonalized rights, from which they can enjoy and obtain judicial protection in case of violation, and their treatment as things is forbidden. In its justification it argues that animals are sentient, but it also does not define or characterize the proposed new legal nature ${ }^{39}$.

9) Draft Law 7,991/2014 (Chamber of representatives) attributes sui generis legal personality to animals (without defining it), making them subjects of fundamental rights (listed as right to food, physical integrity, freedom, among others), in recognition of their sentience ${ }^{40}$. 
and animal production). In turn, the draft laws that aim to change the legal status of animals are based on sentience, dialoguing with Singer ${ }^{23,41}$. However, there are also draft laws that limit their reach to certain animals, setting themselves as speciesist.

The change in the object status of animals results in the statement that they are not things or the stipulation of an odd situation, without a precise definition of the new status of these living beings in the legal order. It can be seen that even legislative proposals that seek to assign basic rights to animals or change their legal situation do not go into the definition of these concepts. This demonstrates that these very concepts can generate permanent debate ${ }^{42}$, reason due to which they have not been explicitly approached by the proposing congressmen, a list of animal rights being present in only two draft laws.

It is true that even considering the draft laws proposed as progress, there are still issues without immediate resolution. For example, how to assess the pain or death of some animals compared to possible benefits for humans, as well as the disagreement among theorists themselves about what treatment should be given to animals ${ }^{43}$.

In addition, it remains impossible to measure damage and suffering for animals and humans. It is almost impossible to compare the claim that animals do not suffer serious damage with that which defines that humans should not suffer milder harm. Consider the fact that moral reality is more chaotic and complex than theories portray must be considered ${ }^{44}$. Likewise, the question remains as to how the proposed changes in the status of animals will be reflected and absorbed by the social structure (e.g. in the large-scale production system or in scientific research).

\section{Final Considerations}

Throughout history, human beings have had feelings of inferiority and sacredness toward animals. However, in most present-day societies there is a stance of superiority, dominance and disposal over other living beings. This way, it is evident that the existing relationship is not fixed and, in Brazil, there is a time for discussion and reflection about the theme.

The Brazilian legal system is based on the perspective that the law is a human construct and, thus, the only and irreducible measure is the man. With this, the law would be structured on the pillar of anthropocentrism ${ }^{45}$, but there are already proposals to modify or displace that vision, as can be seen from some of the legislative proposals under way. Still, even draft laws that aim to assign rights or alter the legal status of animals can perpetuate discriminatory positions regarding animal species, privileging vertebrates.

The debate about the legal status of animals permeates the debate about the breakdown of the anthropocentric paradigm, especially after scientific discoveries about biology, etiology and animal genetics. In the 21st century, this debate became part of the agenda of the Brazilian National Congress, reflecting the discussion that exists in the society, especially in the legal environment ${ }^{46-}$ 48. Therefore, although the national legal system is based on the anthropocentric perspective, the existence of legislative proposals demonstrates the attraction of the debate for the legal sector ${ }^{49}$ and shows a chronological evolution of the view that animals would be entitled to rights.

This view is justified by the recognition of their sentience, seeking to move away from the current anthropocentric and speculative perspective, in line with Singer's arguments ${ }^{23,41}$. This new context may result in the transition or overcoming of the current perspective in Brazil, leading the debate to reflect in what way and what activities (creation, fun, scientific etc.) will be changed, expressing new social values that will directly affect the legal framework which will be attributed to animals by the Legislative Power.

\section{Referências}

1. Bowman JC. Animais úteis ao homem. São Paulo: EPU; 1980. v. 20. (Coleção Temas de Biologia)

2. Fagundes DJ, Taha MO. Modelo animal de doença: critérios de escolha e espécies de animais de uso corrente. Acta Cir Bras. 2004;19(1):59-65.

3. Schanaider A, Silva PC. Uso de animais em cirurgia experimental. Acta Cir Bras. 2004;19(4):441-7.

4. Rifkin J. O século da biotecnologia: a valorização dos genes e a reconstrução do mundo. São Paulo: Makron; 1999.

5. Gaspar MD. Cultura: comunicação, arte, oralidade na pré-história do Brasil. Rev Mus Arqueol e Etnologia. 2004;14:153-8. 
6. Pessis AM. Imagens da pré-história: Parque Nacional Serra da Capivara. 2a ed. São Paulo: Fumdham Ed; 2013.

7. Pastoureau M. Os animais célebres. São Paulo: Martins Fontes; 2015.

8. Orwell G. A revolução dos bichos. São Paulo: Globo; 2003.

9. Kafka F. A metamorfose. 7ạ ed. Rio de Janeiro: Civilização Brasileira; 1997.

10. Carroll L. Aventuras de Alice no País das Maravilhas e através do Espelho e o que Alice encontrou por lá. Rio de Janeiro: Jorge Zahar; 2009.

11. Cascudo C. Contos tradicionais do Brasil. 18ª ed. Rio de Janeiro: Ediouro; 2003.

12. Reale M. Lições preliminares de direito. 27a ed. São Paulo: Saraiva; 2002.

13. Betioli $A B$. Introdução ao direito: lições de propedêutica jurídica tridimensional. 10a ed. São Paulo: Saraiva; 2008.

14. Pedrosa RL. Direito em história. 6a ed. Rio de Janeiro: Lumen Juris; 2008.

15. Ramayana M. Estatuto do idoso comentado. Rio de Janeiro: Roma Victor; 2004.

16. Colaço TL. O direito indígena pré-colonial. In: Wolkmer AC, organizador. Direito e justiça na América indígena: da conquista à colonização. Porto Alegre: Livraria do Advogado; 1998. p. 111-42.

17. Castro FL. História do direito: geral e Brasil. 8a ed. Rio de Janeiro: Lumen Juris; 2010.

18. Reale M. Filosofia do direito. 20a ed. São Paulo: Saraiva; 2010.

19. Nader P. Introdução ao estudo do direito. 33a ed. Rio de Janeiro: Forense; 2011.

20. Nader P. Filosofia do direito. 19a ed. Rio de Janeiro: Forense; 2010.

21. Brasil. Conselho Federal de Medicina. Resolução no 2.121, de 16 de julho de 2015. Adota as normas éticas para a utilização das técnicas de reprodução assistida. [Internet]. Diário Oficial da União. Brasília; 24 set 2015 [acesso 23 fev 2016]. Seção 1. Disponível: http://bit.ly/1NW9tTQ

22. Dias EC. A tutela jurídica dos animais. Belo Horizonte: Mandamentos; 2000.

23. Singer P. Libertação animal. Porto Alegre: Lugano; 2004.

24. Naconecy CM. Ética e animais: um guia de argumentação filosófica. Porto Alegre: EDIPUCRS; 2006.

25. Brasil. Presidência da República. Decreto no 16.590, de 10 de setembro de 1924. Aprova o regulamento das casas de diversões públicas. [Internet]. Diário Oficial da União. Rio de Janeiro; 13 set 1924 [acesso 15 fev 2016]. Disponível: http://bit.ly/2jPDOtq

26. Brasil. Presidência da República. Lei no 9.605, de 12 de fevereiro de 1998. Dispõe sobre as sanções penais e administrativas derivadas de condutas e atividades lesivas ao meio ambiente, e dá outras providências. [Internet]. Diário Oficial da União. Brasília; 13 fev 1998 [acesso 15 fev 2016]. Disponível: http://bit.ly/1La6hQT

27. Brasil. Presidência da República. Decreto-Lei no 3.688, de 3 de outubro de 1941. Lei das Contravenções Penais. [Internet]. Diário Oficial da União. Brasília; 3 out 1941 [acesso 15 fev 2016]. Disponível: http://bit.ly/1U2PfLP

28. Brasil. Presidência da República. Lei no 11.794 , de 8 de outubro de 2008. Estabelece procedimentos para o uso científico de animais. [Internet]. Diário Oficial da União. Brasília; 9 out 2008 [acesso 23 nov 2016]. Disponível: http://bit.ly/1WV52wP

29. Regis AHP, Cornelli G. Experimentação animal: panorama histórico e perspectivas. Rev. bioét. (Impr.). 2012;20(2):232-43.

30. Brasil. Presidência da República. Constituição da República Federativa do Brasil, de 5 de outubro de 1988. [Internet]. Diário Oficial da União. Brasília; 5 out 1988 [acesso 15 fev 2016]. Disponível: http://bit.ly/1dFiRrW

31. Brasil. Presidência da República. Lei no 10.406, de 10 de janeiro de 2002. Institui o Código Civil. [Internet]. Diário Oficial da União. Brasília; 11 jan 2002 [acesso 15 fev 2016]. Disponível: http://bit.ly/1hBawae

32. Brasil. Senado Federal. Projeto de Lei no 351, de 10 de junho de 2015. Acrescenta parágrafo único ao art. 82, e inciso IV ao art. 83 da Lei no 10.406, de 10 de janeiro de 2002 (Código Civil), para determinar que os animais não serão considerados coisas. [Internet]. Brasília; 2015 [acesso $18 \mathrm{fev}$ 2016]. Disponível: http://bit.ly/2kKZsh7

33. Brasil. Senado Federal. Projeto de Lei no 631, de 23 de setembro de 2015. Institui o Estatuto dos Animais e altera a redação do art. 32 da Lei no 9.605, de 12 de fevereiro de 1998. [Internet]. Brasília; 2015 [acesso 18 fev 2016]. Disponível: http://bit.ly/2jqqAVx

34. Brasil. Senado Federal. Projeto de Lei no 650, de 29 de setembro de 2015. Dispõe sobre a proteção e defesa do bem-estar dos animais e cria o Sistema Nacional de Proteção e Defesa do Bem-Estar dos Animais (Sinapra); o Conselho Nacional de Proteção e Defesa do Bem-Estar dos Animais (Conapra); altera a redação do art. 20 da Lei no 7.173, de 14 de dezembro de 1983; altera a redação do art. 32 da Lei no 9.605, de 12 de fevereiro de 1998; acrescenta o $\S 40$ ao art. 10 da Lei no 11.794, de 8 de outubro de 2008, e revoga a Lei no 10.519, de 17 de junho de 2002. [Internet]. Brasília; 2015 [acesso 18 fev 2016]. Disponível: http://bit.ly/2kcgTYd

35. Brasil. Senado Federal. Projeto de Lei no 677, de 7 de outubro de 2015. Institui o Estatuto dos Animais, altera a Lei no 9.605, de 12 de fevereiro de 1998, que dispõe sobre as sanções penais e administrativas derivadas de condutas e atividades lesivas ao meio ambiente, e dá outras providências. [Internet]. Brasília; 2015 [acesso 18 fev 2016]. Disponível: http://bit.ly/2jyob6x

36. Brasil. Câmara dos Deputados. Projeto de Lei no 215, de 15 de fevereiro de 2007. Institui o Código Federal de Bem-Estar Animal. [Internet]. Brasília; 2007 [acesso 22 fev 2016]. Disponível: http:// bit.ly/2kmtRow

37. Brasil. Câmara dos Deputados. Projeto de Lei no 2.156, de 30 de agosto de 2011. Institui o Código 
Nacional de Proteção aos Animais. [Internet]. Brasília; 2011 [acesso 22 fev 2016]. Disponível: http://bit.ly/2kmEhnJ

38. Brasil. Câmara dos Deputados. Projeto de Lei no 3.676, de 12 de abril de 2012. Institui o Estatuto dos Animais. [Internet]. Brasília; 2012 [acesso 22 fev 2016]. Disponível: http://bit.ly/2kPCKDA

39. Brasil. Câmara dos Deputados. Projeto de Lei no 6.799, de 20 de novembro de 2013. Acrescenta parágrafo único ao art. 82 do Código Civil para dispor sobre a natureza jurídica dos animais domésticos e silvestres, e dá outras providências. [Internet]. Brasília; 2013 [acesso 18 fev 2016]. Disponível: http://bit.ly/2kNifeP

40. Brasil. Câmara dos Deputados. Projeto de Lei no 7.991, de 24 de setembro de 2014. Altera a Lei no 10.406, de 10 de janeiro de 2002, que institui o Código Civil. [Internet]. Brasília; 2014 [acesso 18 fev 2016]. Disponível: http://bit.ly/2jqiKv6

41. Singer P. Ética prática. São Paulo: Martins Fontes; 2002.

42. Paixão RL, Schramm FR. Experimentação animal: razões e emoções para uma ética. Niterói: EdUFF; 2008.

43. Philp RB. We cannot afford to lose the animal rights war. CMAJ. 1990;142(12):1421-3.

44. Li HL. Animal research, non-vegetarianism, and the moral status of animals: understanding the impasse of the animal rights problem. J Med Philos. 2002;27(5):589-615.

45. Silva JR. Paradigma biocêntrico: do patrimônio privado ao patrimônio ambiental. Rio de Janeiro: Renovar; 2002. p. 213.

46. Bizawu SK. Direitos dos animais: desafios e perspectivas da proteção internacional. Belo Horizonte: Arraes; 2015.

47. Lourenço DB. Direito dos animais: fundamentação e novas perspectivas. Porto Alegre: Fabris; 2008.

48. Nogueira VMD. Direitos fundamentais dos animais: a construção jurídica de uma titularidade para além dos seres humanos. Belo Horizonte: Arraes; 2012.

49. Regan T. Jaulas vazias: encarando o desafio dos direitos animais. Porto Alegre: Lugano; 2006.

\section{Participation of the authors}

This study was carried out during the preparation of the doctoral thesis of Arthur H. P. Regis by the Graduate Program in Bioethics of the University of Brasilia (UnB), UNESCO Chair in Bioethics, supervised in its entirety, by Gabriele Cornelli.

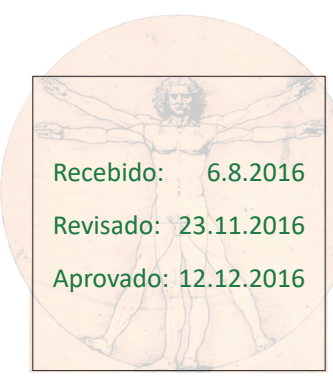


